

Journal of Academic Writing

Vol. 10 No 1 WINTER 2020, pages 165-170 https://doi.org/10.18552/joaw.v10i1.609

\title{
Adapting to a Disciplinary Discourse: A Redesigned Course for MA History Students
}

\author{
Juljia E. But \\ Ural Federal University, Russia
}

\begin{abstract}
For most MA programs, it is common to enroll students with different BA degrees. The MA students who have changed their discipline are required to adopt a new disciplinary discourse and learn to write academic texts in line with appropriate genres and conventions. This study exemplifies an attempt to redesign the academic writing course for MA History programs at the Ural Federal University in order to ease the difficulties faced by students with non-history backgrounds. The essence of the redesign was to enhance the traditional teaching by demonstrating fundamental dissimilarities between history and other disciplines in terms of writing conventions. Teaching academic writing in that manner was supposed to facilitate students with both a history and non-history backgrounds to master the effective conventional writing of history texts. The efficiency of the redesigned course was estimated on the basis of students' performance and feedback. This teaching practice can be of use for academic writing instructors who seek to help students from different backgrounds develop skills and competences that are necessary for a specific professional community.
\end{abstract}

\section{Introduction}

Universities throughout the world regularly enroll MA students with different educational backgrounds. These students, in addition to learning a large amount of new theoretical and practical material, have to adopt a different disciplinary discourse and new writing conventions. If they succeed, their previous knowledge effectively contributes to the research they do, which brings in fresh eyes on a problem, innovative approaches, and lateral thinking. On the other hand, if they fail to shift to new writing standards, it results in writing assignments of poor quality, fruitless attempts to apply for grants, and rejected papers for conferences or journals. My study is therefore aimed at finding ways to assist students to adjust their writing skills to a different disciplinary discourse. It exemplifies an attempt to redesign a particular course, Academic Writing for MA History Students, which I teach at the Ural Federal University (Ekaterinburg, Russia).

In Russian universities, academic writing as an independent discipline is a recent innovation. Russian students do not receive any systematic training in academic writing in secondary school or during their undergraduate studies. This is mainly because the continental mode of writing has long dominated education and research in Russia. Being primarily concerned with content rather than structure, the continental writing is specific to an individual teacher. It provides neither concrete and operational criteria nor formats of structures, and it does not imply any kind of instruction before or during writing (Rienecker \& Jörgensen, 2003, pp. 107108). The current demand for internationalization of research, however, has made university administration switch to the Anglo-American tradition of writing, which is "heavily influenced by rhetorical text-concerns such as purpose, aim, reader, focus, structure and argumentation" (Rienecker \& Jörgensen, 2003, p. 105). Unlike the continental tradition, the Anglo-American mode of writing has a complementary pedagogy, which can be used in writing courses. Russian universities launched academic writing courses in 2010, but they are not available at every Russian university and every program so far. There is hardly any uniformity of teaching writing 
courses among universities and disciplines. Depending on a program, a writing course can be both mandatory and optional, and instruct academic literacies both in English and in Russian. It can be delivered either by a specialist in a discipline (like in my case) or by an invited teacher from the Department of Linguistics. There are normally no institutional pressures regarding the choice of approaches. ${ }^{1}$ Writing courses are mostly stand-alone; at least to my knowledge, there have been no successful experiments with instructing academic literacies embedded within a discipline-specific course, unlike institutes in Europe and other parts of the world (McWilliams \& Quentin, 2014).

In my view, one of the serious shortcomings of the newly introduced writing courses for MA students in Russia is their focus on teaching generic writing skills and genres, which makes them similar to EAP courses in terms of theoretical approaches (Hyland, 2006). Russian authors often refer to this teaching as transdisciplinary writing and consider it a "necessary condition for a flexible interdisciplinary and inter-institutional model of writing instruction" (Korotkina, 2018a, p. 17). Of course, teaching a generic set of writing skills include sample resources from particular disciplines as illustrations. But what value, as Basturkmen justly enquired, do "such texts, topics and tasks hold for students from other disciplines" (2017, p. 35)? Although I do not undervalue the necessity of teaching generic models (as far as most Russian MA students are unfamiliar with them), they should not overshadow the disciplinespecific approach. To be fully-fledged members of the discipline, students need to be familiar with the disciplinary discourse and be able to perform its written genres (Costley \& Flowerdew, 2017, p. 4). Within an MA curriculum, an academic writing course is the course from which students - especially those with a different background - most commonly expect to obtain knowledge of the disciplinary-specific writing.

At the Ural Federal University (UFU), the Department of History, Academic Writing for MA History Students was first introduced as a distinct course as late as in 2015 for MA students of European Historical and Cultural Studies. Between 2015 and 2019, the program enrolled students with a BA degree in history as well as in other humanities, arts, social sciences, and even natural sciences. Students with a history background steadily performed markedly better than those with a non-history background, especially in writing assignments and thesis writing. Having found out about the problems typically faced by students with a different background, I sought to revise the content of my writing course.

\section{Theoretical Frameworks}

I thought of understanding of disciplinary writing as the learning outcome of my course and put in sharp focus the discipline-specific approach which has a firm theoretical basis in literature (Christie \& Maton, 2011; Eriksson, 2018; Flowerdew \& Costley, 2017; Kaldor \& Rochecouste, 2002). Of course, I could not completely avoid a generic approach when teaching metalinguistic competences, for instance, referencing or paragraphing. However, I focused students' attention on learning "cultural means, tools, and signs" of the history environment (Elon University, 2015, p. 4) and developing the discourse competence, which is central to the mastery of academic writing (Bruce, 2008, p. 1).

My course design also rested on several current strands of pedagogy, notably the transfer theory which refers to how previous learning influences current and future learning (Devet, 2018, pp. 191-192; Donahue, 2016, pp. 109-110; Haskell, 2001, p. 23), and cultural-historical activity theory, which sheds light on contradictions faced both by teachers and students when the latter move from writing in one discipline to writing in another (Russell \& Yañez, 2003; Tuomi-Gröhn \& Engeström, 2003). The reader-oriented approach was strongly emphasized throughout the course to teach students how to engage proficiently with their readers (Hyland, 2010, p. 194).

\footnotetext{
${ }^{1}$ See Korotkina (2016 and 2018b) for more details on writing instruction in Russia.
} 


\section{Course Design and Participants}

Cooperation with the profile subject teachers was important for me. Prior to redesigning, I organized a meeting with my colleagues who teach profile subjects at the Department of History in order to pinpoint the challenges faced by MA students with non-history backgrounds and to find out how the staff imagined the anticipated redesign. My colleagues unanimously stressed a number of the most common problems, including students' ineptitude to formulate a good title, put inquiry questions, describe approaches and methods, process historical sources, and avoid fallacies in argumentation. My colleagues' comments and recommendations on the course redesign were given due consideration.

My redesigned course Academic Writing for MA History Students was tested during the fall semester of 2018 with a group of first-year MA students. Most of them were students of European Historical and Cultural Studies for whom this course was mandatory. Eight MA students from other programs joined them as volunteers. 11 of the 23 students had a history background. 12 of them had BA degrees in political sciences, linguistics, philosophy, journalism, international relations, sociology, pedagogy, and economics.

The course was delivered through thirteen weekly, two-hour workshops during the first semester of the two-year MA program. Being mandatory for some students, it was credited as a 72-hour, two-credit course. The first part of the syllabus covered such traditional topics of the Anglo-American mode of writing as Cross-Cultural Differences in Academic Texts, Text Organization: The Macro- and Micro-Levels, Argumentation and Logical Fallacies, Plagiarism, References and Ethics, and Digital Literacy of a Researcher. The second part consisted of four topics - Publication Activity, A Research Paper, A Book Review, and Thesis Writing for a Master's Degree. I enhanced my course with extensive illustrative material from publications in history to provide examples of good and bad text structure, relevant and irrelevant evidence, logical and wrong arguments, plagiarism, logical fallacies, ambiguities, pleonasm, etc. I understood, however, that samples from history papers would not be quite comprehensible for students with non-history backgrounds. I sought, therefore, to revise the content of the topics which I will describe later in this paper.

The MA students had two writing assignments. One of them was to write an argument essay of approximately 2,000 words on a historical issue relevant to a student's research problem. Another assignment was to compose a book review of approximately 1,000 words. Thus, the students could practice the Anglo-American mode of writing in typical genres of history. Although history shares these genres with other disciplines, there are different genre norms (Russell \& Yañez, 2003, p. 348). The low word count was intentionally designated as an important tool to teach students to summarize and write in a balanced and concise manner (Hawley, 2018, p. 69). I found the two genres most relevant for MA students for several reasons. First, both fit the students' level of training. According to the curriculum, my course was preceded by a research period during which students were reading literature related to their future MA theses; so as a result, everyone had a particular research problem and a recent history book fresh in mind. Secondly, it caters to students' need to publish in order to receive a higher stipend, to obtain financial support for their research and to successfully defend their theses. A student could further elaborate the final drafts and publish them in a journal for novice researchers or, in case of collaboration with a supervisor, in a history journal. Thirdly, a book review as a type of publication is underdeveloped in Russia and efforts are being made to reduce a gap between Russian and foreign journals in this respect. The two assignments were graded on a scale of 100 points which is approved at the UFU, with the grading criteria being largely based on those for the IELTS Academic Writing test.

\section{Assessment of the Effectiveness}

The first signs in favor of my redesign appeared already during the in-class practical activities. Following each topic of the course, students got tasks aimed at familiarizing themselves with peculiarities of history genres (e.g. to restore the order of sentences in a paragraph, find a logical fallacy, include a phrase of a reputable historian in one's own writing, correct the title, 
etc.). In previous years students were able to finish only two and occasionally three tasks within the allotted time. That was because students with non-history backgrounds worked slowly; moreover, it took plenty of time to explain to them what they did wrong. Meanwhile, bored students with a history background naturally found this annoying. After the course redesign, the atmosphere in the classroom became much livelier. The students regularly managed to complete three or four tasks, explanation of errors took less time, and, which is most important, the students with non-history backgrounds performed almost as well as those with a history one.

Secondly, I compared the difference between the average grades for the writing assignments by the students with a history background and the writing assignments by the students with non-history backgrounds. In 2015, 2016 and 2017 this difference was 19.6, 16.5 and 17.2 points respectively, whereas in 2018 it was only 3.2 points (while the performance of students with a history background also improved, and the average grade was a bit higher than in previous years). The results suggested that the redesign made it possible to reduce the gap between the writing competences of the two categories of students. Additionally, after the course was over, the profile subject lecturers appreciated in private conversations the more professionalsounding writings by students with non-history backgrounds as compared to previous years.

The students' feedback forms demonstrated that they, by and large, found the course content informative and useful, and recognized the teaching strategy as suitable and helpful. The students with non-history backgrounds were generally satisfied with the time allotted for the course topics unlike the previous years, when more in-class instruction was demanded. Finally, soon after the course, four MA students with non-history backgrounds took part in one of the UFU's annual conferences for young researchers and got their abstracts published in the volume of the proceedings (Babintsev et al., 2019). I regard this as an indirect evidence of my redesign's efficiency because previously first-year MA students with non-history backgrounds had no publications in history.

\section{Conclusion}

This teaching practice aimed to address MA student diversity in terms of their background and prior experience of academic writing. The course Academic Writing for MA History Students was redesigned to cater to the literacy needs of students both with a history and non-history backgrounds. The course content was revised to display the differences between the writing conventions in history and in the disciplines of the course participants. The effectiveness of the redesigned course was assessed following the students' writing progress and feedback. The results showed that the quality of the students' writing had improved, with a gap in the writing competences between the two categories being significantly reduced. This leads to the conclusion that the redesign helped the MA students with a different background to adjust to history writing conventions and genres, which were partially or largely new to them.

Of course, the conclusion is based on limited data. I should point out, however, that my initiative was appreciated by the department administration. At the start of the 2019/2020 academic year, the redesigned course Academic Writing for MA History Students was introduced as a mandatory one in the curricula of both MA History programs at UFU - European Historical and Cultural Studies and Russian History. The main principles of the developed strategy have served as basis for the newly introduced writing courses in other MA programs at UFU related to anthropology, ethnology, archival studies, public service, event management, and international tourism. The described teaching strategy can be applied, to varying degrees, by academic writing instructors who work with students from different backgrounds and help them to develop control of new disciplinary forms and writing competences.

\section{Acknowledgements}

This work was supported by the Vladimir Potanin Foundation; the author is the winner of the 2017/2018 Vladimir Potanin Fellowship. 


\section{References}

Babintsev, V. A., Baranov, N. N., Bespalova, K. A., Sidorkina, T. S., \& Masaleva, A. Y. (Eds.). (2019). Clio moderna: Problems of modern and contemporary world history. Abstracts and reports of the All-Russia scientific conference of young scientists dedicated to the anniversary of History Department of the Ural Federal University November 16-17, 2018, Ekaterinburg, Russia. Armchair Scientist.

Basturkmen, H. (2017). Developing writing courses for specific academic purposes. In J. Flowerdew \& T. Costley (Eds.), Discipline-specific writing: Theory into practice (pp. 3145). Routledge.

Bruce, J. (2008). Academic writing and genre: A systematic analysis. Continuum.

But, Y. (2019). Akademicheskoe pis'mo dlya istorikov: uchebnoe posobie [Academic writing for history students: A Tutorial]. Izdatel'skii otdel UrGPU.

Coffin, C., \& Hewings, A. (2003). Writing for Different Disciplines. In C. Coffin, M. J. Curry, S. Goodman, A. Hewings, T. M. Lillis, \& J. Swann (Eds.), Teaching academic writing: A Toolkit for higher education (pp. 45-72). Routledge.

Coffin, C. (2006). Historical discourse: the language of time, cause and evaluation. Continuum.

Curry, M. J., \& Hewings, A. (2003). Approaches to teaching writing. In C. Coffin, M. J. Curry, S. Goodman, A. Hewings, T. M. Lillis, \& J. Swann (Eds.), Teaching academic writing: A Toolkit for higher education (pp. 19-44). Routledge.

Costley, T., \& Flowerdew, J. (2017). Introduction. In J. Flowerdew \& T. Costley (Eds.), Discipline-specific writing: Theory into practice (pp. 1-11). Routledge.

Christie, F., \& Maton, K. (2011). Why disciplinarity? In R. Christie \& K. Maton (Eds.), Disciplinarity: functional linguistic and sociological perspectives (pp. 1-9). Continuum.

Devet, B. (2018). How tutors of academic writing can use the theory of transfer of learning. Journal of Academic Writing, 8(2), 191-201. https://doi.org/10.18552/joaw.v8i2.437

Donahue, C. (2016). Writing and global transfer narratives: Situating the knowledge transformation conservation. In C. Anson \& J. Moore (Eds.), Critical transitions: Writing and the question of transfer (pp. 107-137). WAC Clearinghouse/University Press of Colorado.

Elon University: Center for Engaged Learning. (2015). Elon Statement on Writing Transfer. https://www.centerforengagedlearning.org/critical-transitions-writing-and-thequestionof-transfer/elon-statement-on-writing-transfer

Eriksson, A. (2018). Redesigning a discipline-specific writing assignment to improve writing on an EMI programme of engineering. Journal of Academic Writing, 8(2), 48-66. https://doi.org/10.18552/joaw.v8i2.496

Flowerdew, J., \& Costley, T. (Eds.). (2017). Discipline-specific writing: Theory into practice. Routledge.

Fischer, D. H. (1970). Historian's fallacies: Toward a logic of historical thought. Harper Perennial.

Haskell, R. (2001). Transfer of learning: Cognition, instruction, and reasoning. Academic. 
Hawley, R. (2018). Academic writing as embedded skills acquisition for transition to higher education: An example from a UK university classics department. Journal of Academic Writing, 8(2), 67-77. https://doi.org/10.18552/joaw.v8i2.483

Hyland, K. (2006). English for academic purposes: An advanced resource book. Routledge.

Hyland, K. (2010). Researching writing. In B. Paltridge \& A. Phakiti (Eds.). Continuum companion to second language research methods (pp. 191-204). Continuum.

Kaldor, S., \& Rochecouste, J. (2002). General academic writing and discipline specific writing. Australian Review of Applied Linguistics, 25(2), 29-47. https://doi.org/10.1075/aral.25.2.04kal

Korotkina, I. B. (2016). Shaping academic writing in Russia. In E. Frumina \& L. Bondareva (Eds.), Proceedings of the $3^{\text {rd }}$ International Conference on ESP/EAP/EMI in the context of the higher education internalization (pp. 33-42). National University of Science and Technology MISIS.

Korotkina, I. B. (2018a). Modeli obucheniya akademicheskomu pismu [Teaching Models of Academic Writing]. Izdatel'stvo 'Yurait'.

Korotkina, I. B. (2018b). University writing centers in Russia: Balancing unity and diversity. Higher Education in Russia and Beyond (HERB), 2(16), 6-7. https://herb.hse.ru/en/2018--2(16).html

McWilliams, R., \& Allan, Q. (2014). Embedding academic literacy skills: Towards a best practice model. Journal of University Teaching \& Learning Practice, 11(3). http://ro.uow.edu.au/jutlp/vol11/iss3/8

Rienecker, L., \& Jörgensen, P. S. (2003). The (Im)Possibilities in teaching university writing in the Anglo-American tradition when dealing with continental student writers. In L. Björk, G. Bräuer, L. Rienecker, \& P. S. Jörgensen (Eds.), Teaching academic writing in European higher education (pp. 101-112). Kluwer Academic Publishers.

Russell, D. R., \& Yañez, A. (2003). "Big picture people rarely become historians": Genre systems and the contradictions of general education. In C. Bazerman \& D. Russell (Eds.), Writing selves / Writing societies: Research from activity perspectives. Perspectives on writing (pp. 331-362). The WAC Clearinghouse; Mind, Culture, and Activity. https://wac.colostate.edu/books/perspectives/selves-societies

Tuomi-Gröhn, T., Engeström, Y., \& Young, M. (2003). From transfer to boundary-crossing between school and work as a tool for developing vocational education: An Introduction. In T. Tuomi-Gröhn \& Y. Engeström (Eds.), Between School and Work: New Perspectives on Transfer and Boundary-crossing (pp. 1-15). Emerald Group Publishing. 